pathway now available, and hence galactose transfor is inhibited.

Other explanations are also possible. There may be one mechanism for entry of hexoses into the cell, and the separation into two pathways--one uranyl sensitive leading into metabolism-may occur inside the cell. In this case it must be postulated that the uranyl sensitive pathway is not available to glucoso initially presont in tho serosal fluid. Another possibility is that uranyl ions may penetrate only into a limited part of the cell and may affect metabolism of part of the cell into which glucose from the serosal side of the cell does not penetrate.

Of considerable interest is the stimulation of galactose transfer by small concentrations of glucose. Fishor and Parsons ${ }^{4}$ showed that glucose and galactose compete for entry, and while the present results support this they also show that provided glucose is present in small concentrations in the mucosal fluid or in higher concentrations in the serosal fluid, it may be able to enter the cell without competing with galactose and by its metabolism stimulate galactose transfer. This would be in keeping with the results of Nowey and Smyth", who have shown that glucose metabolism can stimulate glycino transfer. It thus appoars that glucoso metabolism can supply energy for three different transfer systems, that is, galactose, glycine and fluid.

We thank the Medical Research Council and John Wyeth and Brother for grants towards expenses.

H. NEWEY

P. A. SANBORD

D. H. Sмутн

Department of Physiology,

University of Sheffield.

' Rothstein, A., Circulation, 26, 1189 (1962).

2 Ponz, F., Rev. esp. Fisiol., 8, 217 (1952)

3 Ponz, F., and Tluch, M., Rev. esp. Fisiol., 14, 217 (1958).

‘ Fisher, H. B., and Parsons, D. S., J. Physiol.,119, 224 (1953).

'Newey, H., and Smyth, D. II., J. Physiol., 104, 527 (1902).

\section{Identification of Oestradiol and Oestrone in Avian Plasma}

Authougr it has long been held that the plasma of the laying domestic fowl contains oestrogenic substances no direct identification has beon reported. Although oestrono, oestradiol and oestriol have been identified in extracts of ovarian tissue from the laying hon ${ }^{1}$ and also in urine ${ }^{2,3}$, attempts to detect oestrogens in blood have been unsuccessful.

As part of an investigation of factors involved in yolk production in the domostic fowl this problem has been investigated using a technique of double isotope derivative analysis using carbon-14-labelled oestrogens and tritiated dimethyl sulphate as identifying agents.

Plasma from laying hens was troated with hydrochloric acid $^{5}$ to hydrolyse conjugated oestrogens, and after extraction with chloroform was separated into fractions presumptively containing oestradiol + oostrono and oestriol". The fractions were methylated with dimethyl sulphate- $T$ and, after romoval of solvents and decomposition of excess dimothyl sulphate with alkali, were extracted into hexane. Authentic methylated ${ }^{14} \mathrm{C}$ oestradiol and oestrone were then added and the methyl oestrogens were separated and purified, first by thin-layer chromatography using solvent systems $A, \dot{B}$ and $O$ of Lisboa and Diozfaluzy ${ }^{8}$, followed by chromatography on columns of propared alumina. Samples of each frection were counted in a liquid scintillation counter.

It was found that the samples of both mothyl oestradiol and methyl oestrone contained tritium, the ratios of tritium/ $/{ }^{12} \mathrm{C}$ becoming constant after several fractionations (Table 1). As a further check on the chromatographic homogeneity, fractions oluted from the second alumina column (Table 1) were re-chromatographed on alumina and the three fractions comprising the beginning, the

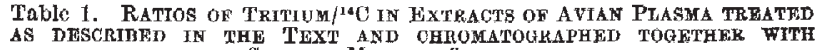
AS DESCRIBED IN THE TEXT AND OHROMATOGKAPH

\begin{tabular}{|c|c|c|c|c|c|c|}
\hline \multirow[b]{2}{*}{$\begin{array}{l}\text { Solvent } \\
\text { systems }\end{array}$} & \multicolumn{3}{|c|}{ Methyl oestrone } & \multicolumn{3}{|c|}{ Methyl oestradiol } \\
\hline & $\underset{\text { (c.p.,in.) }}{\mathrm{T}}$ & $\begin{array}{c}{ }^{14} \mathrm{C} \\
(0 . \mathrm{p} . \mathrm{m} .)\end{array}$ & $\begin{array}{l}\text { Ratio } \\
\left(\mathrm{T} /{ }^{14} \mathrm{C}\right)\end{array}$ & $\begin{array}{c}\mathrm{T} \\
\text { (c.p.m.) }\end{array}$ & $\begin{array}{c}{ }^{14} \mathrm{C} \\
\text { (c.,p, IIr.) }\end{array}$ & $\begin{array}{l}\text { Ratio } \\
\left(\mathrm{T} /{ }^{10} \mathrm{C}\right)\end{array}$ \\
\hline lumine & $\begin{array}{l}2.86 \times 10^{5} \\
6.9 \times 10^{3} \\
4 \cdot 71 \times 10^{3} \\
1.45 \times 10^{3} \\
1.07 \times 10^{8}\end{array}$ & $\begin{array}{r}460 \\
319 \\
126 \\
73 \\
57\end{array}$ & $\begin{array}{l}37 \\
10 \\
18\end{array}$ & $\begin{array}{l}1.72 \times 10^{3} \\
1.53 \times 10^{\mathrm{a}}\end{array}$ & $\begin{array}{r}324 \\
293 \\
166 \\
102 \\
75\end{array}$ & $\begin{array}{r}513 \cdot 0 \\
69 \cdot 0 \\
19 \cdot 8 \\
18 \cdot 1 \\
20 \cdot 2\end{array}$ \\
\hline
\end{tabular}

Table 2. Ratros of Trimum $/{ }^{14} \mathrm{O}$ IN likadTons From the ColdUMNS ALUMTNA 2, of Table 1, Refrachionated un a Fresh alumina Column

\begin{tabular}{|c|c|c|c|c|c|c|}
\hline \multirow[b]{2}{*}{$\begin{array}{l}\text { Fraction } \\
\text { number }\end{array}$} & \multicolumn{3}{|c|}{ Mothyl oestrone } & \multicolumn{3}{|c|}{ Methyl oestradiol } \\
\hline & $\underset{(c, p, I n,)}{T}$ & $\begin{array}{c}10 \mathrm{O} \\
\text { (c.p.m.) }\end{array}$ & $\begin{array}{c}\text { Ratio } \\
\left(\mathrm{I}^{1 / 4} \mathrm{C}\right)\end{array}$ & $\begin{array}{c}\mathrm{T} \\
(c, p, \mathrm{~m} .)\end{array}$ & $\begin{array}{c}14 \mathrm{C} \\
(c, p, \mathrm{~m} .)\end{array}$ & $\begin{array}{l}\text { Ratio } \\
\left(\mathrm{T} / /^{14} \mathrm{C}\right)\end{array}$ \\
\hline $\begin{array}{l}2 \\
3 \\
4\end{array}$ & $\begin{array}{l}97 \cdot 1 \\
1 \cdot 07 \times 10^{8} \\
336\end{array}$ & $\begin{array}{c}4.5 \\
57 \\
17 \cdot 0\end{array}$ & $\begin{array}{l}21.4 \\
18.7 \\
19.68\end{array}$ & $\begin{array}{l}415.0 \\
1.53 \times 10^{3} \\
124.2\end{array}$ & $\begin{array}{l}19 \\
75 \\
18\end{array}$ & $\begin{array}{l}21 \cdot 9 \\
20 \cdot 2 \\
20.7\end{array}$ \\
\hline
\end{tabular}

middle and the end of each elution peak were separately collected. The tritium $/{ }^{14} \mathrm{C}$ ratios in each were found to be the same within the limits of experimental error ('Table 2). At no time was tritium detectable in chromatographic areas corresponding to authentic mothyl oestriol.

The results show that materials are present in hydrolysates of avian plasma which after methylation behave in a manner identical with methyl oestrono and methyl oestradiol in several solvent systems. Such behaviour is considered to be proof of idontity and to show the oxistence of oostradiol and oestrone, or their conjugates, in avian plasma.

We thank Cyril Thornber, Ltd., Mytholmroyd, Halifax, for a generous supply of birds.

Twyford Laboratories, Ltd.,

\section{J. E. O'Grady \\ P. J. HeALD}

Twyford Abbey Road, London, N.W.10.

'Layne, D. S., Common, R. H., Maw, M. A., and Fraps, R. M., Nature, 181, 351. (1) 158 ),

'Ainsworth, L., and Common, R. H., Nature, 195, 77 (1962).

Macrae, F. F., Saharia, W., and Common, R. H., Poultry Sch., 88, 318 (1959).

4 Kliman, T., and Peterson, R. E., J. Biol. Chem.,235 1039 (1060).

${ }^{5}$ Roy, E. J., and Brown, J. B., J. Endocrinol., 21, 9 (1900).

'Svendsen, R., Acta Endocrinologica, 34, 161 (1960).

'Lisboa, B. P., and Diczfaluszy, E., Acta Endocrinologica, 40, 60 (1902), ' Brown, J. B., Biochem. J., 60, 185 (1953).

\section{An Extracellular $\alpha$-L-Arabinofuranosidase secreted by Sclerotinia fructigena}

AN earlier communication ${ }^{1}$ reported the resolution of a maceration factor from endopolygalacturonase $(P G)$ in culture filtrates of Sclerotinia fructigena Aderh. and Ruhl., by means of gol filtration on doxtran Sephadex ' $G 75$ ' and chromatography on 'Ecteola'-cellulose. Tho biochemical basis of maceration of potato slices by these preparations was not olucidated, but McClendon' has domonstrated that, in chromatography on cellulose phosphate of an ultra-filtered and freeze-driod sample of our culture filtrate, maceration of potato disks occurred in two peaks, one associatod with a major $\mathrm{PG}$ peak and the other with a minor $\mathrm{PG}$ peak, with indications that arabanase or galactanase may macerato. We have shown independently that arabinose is liberated from potato fibre by a purified 'maceration factor' preparation free of PG and, subsequent to MoClendon's findings, from lupin seed pectate. Incubation of the purified preparation with potato fibre was also accompanied by a rolease of soluble uronide, as determined by the carbazole method ${ }^{8}$ (Fig. 1); the uronide was shown to be of high molecular weight by its failure to pass through a 'Visking' dialysis membrane, suggesting that a partial breakdown of in. soluble 'protopectin' had occurred.

'Protopectin' may owe its insolubility to the presonce of linkages of uronides with galactans and arabans", which are known to consist of chains of $\alpha$-L-arabino- 